\title{
Dialogues across cultures: Adaptations of Chinese verse by Judith Gautier an...
}

Maria Rubins

Comparative Literature; Spring 2002; 54, 2; ProQuest Direct Complete pg. 145

MARIA RUBINS

\section{Dialogues across Cultures: Adaptations of Chinese Verse by Judith Gautier and Nikolai Gumilev}

\author{
But perhaps poetr y itself- \\ Is a single splendid quotation. \\ - Anna Akhmatova \\ I desire to select and transmit the old, \\ So that its splendor will last a thousand rears." \\ - L.i Po
}

W

HEN ONE CUITURE ENGAGES in a dialogue with another, it can often reveal something essential about itself. When two cultures base their interaction on yet a third, an important connection is established that transcends geographical, national, and chronological boundaries. The pre-revolutionary years were for Russian art a period of heightened cosmopolitan interest and creative exploration of foreign traditions. Although Russian writers and artists sought inspiration directly from the West, East, South, and North, they also assimilated a range of traditions through the medium of European civilization. By the early twentieth century, Russia's ties with Western Europe had intensified, and the Russian intellectual elite were traveling and living in Europe for extended periods of time, facilitating the integration of European ideas and artistic styles into Russian culture.

The poetry of Nikolai Gumilev (1886-1921) exemplifies the cosmopolitan spirit that suffused Russian art before the Bolshevik Revolution. The founder and leader of Acmeism, a modernist poetic school of the second decade of the last century, Gumilev drew on many Western models, particularly French ones. The descriptive, plastic aesthetics of the nineteenth-century French Parnassians served as an important source for Acmeism, which emphasized the material quality of the world, verbal precision, and an ideal of harmonious fusion between poetry and the visual arts. Fascinated by various exotic cultures, as were Parnassian poets

${ }^{1}$ From the Cucle "Secrets of the Craft," trans. Judith Hemschemever. The Complete Poems of Anna Akhmalova 703 .

"Ancient Airs," Irans. Joscph I . Lee, Sunflozer Splendor 114. 
Leconte de Iisle and Théophile Gautier, Gumilev turned to Africa, Persia, and the Far East in search of his subject matter. In 1918 he published a thin volume of Chinese verse entitled Farforozyi pavil'on (The Porcelain Pazilion), which contained adaptations of French translations of Chinese poems and was decorated with ideograms and Asian woodblocks from the art collection of the University of Petrograd. Gumilev did not name the Chinese poets; instead. he simply acknowledged his immediate sources, among whom were Judith Gautier, Hervey Saint-Denys, and other French translators. The subsequent 1922 edition, as well as other posthumous publications of Gumilev's verse, included the names of the original Chinese poets, although many were incorrectly identified or misspelled.

The Porcelain Pavilion reflects a peculiarity of Russian modernist culture: it made Orientalism one of its identifying features, but presented Asia largely through the prism of Western European interpretations. Gumilev in this sense was no exception; he traveled to France in order to discover China. ${ }^{3}$ According to Roman Timenchik, the six months the Russian poet spent in Paris in 1917 were instrumental in forming his taste for Asian art; he avidly read French translations of Eastern literature, collected Oriental antiques and books, and began composing a long narrative poem, "Dva sna" ("Two Dreams"), with a Chinese theme (129).

Since Gumilev did not know Chinese, he had to resort to French translations. The first part of The Porcelain Pavilion was based on Le livre de jade (The Book of Jade) by Judith Gautier. a remarkable literary figure, who was so immersed in the Parnassian milieu that she was even referred to by some contemporaries as the only female Parnassian. The initial inspiration for Gumiler's Chinese project can therefore be attributed to both his interest in Parnasse $e^{5}$ and his passion for Chinese culture. This comparative study of translations by Gautier and Gumilev pursues several goals: to reveal new analogies between French and Russian modernist literature: to explore both poet-translators' affinities for the spirit and style of classical Chinese verse: and to determine how these adaptations from Chinese reflect Gumilev's development as a poet. The discussion will inevitably touch upon the deliberate transformation and simple misreading of the Chinese verse by Gautier and-by extension-Gumilev and will, therefore, expose the problem of translation as a projection of the translator's own poetics and cultural agenda.

Judith Gautier (1845-1917), the eldest daughter of illustrious poet and novelist Théophile Gautier, was an accomplished author in her own right. In 1910 she became the first woman admitted to the Academie (ioncourt; and in 1911 she received the cross of the Legion of Honor, France's highest decoration. Most of her literary output consisted of imaginative writing about the Far East, particularly China and Japan. In addition, she wrote several scholarly essavs on Asia, the result of a life-long, dedicated study of Oriental philosophy and culture, and of the Chinese, Japanese and Persian languages. Despite the fact that Judith never

${ }^{3}$ Even Slobodniuk, who in principle rejects the primacy of Western influence in Gumilev's "Oriental works" makes an exception for The Porcelain Pazilion (Slobodniuk 168).

A fow years carlier, in 1914, Gumilev had also written a poem entitled "Kitaishatia devushka" ("A Young Chinese lady").

${ }^{5}$ I explored the influence of Parnasse on Acmeism in my book Crossoad of Arts, Cossoad of Culiures: Ecphrasis in Russian and French Poetry (New York: Palgrave, 2000) 
visited China, the object of her particular fascination, many contemporaries regarded her as a knowledgeable Sinologist. This interest in Asian culture was cultivated in Judith by her father, who was one of the first mid-nineteenth-century writers to revive the fashion for Orientalism.

The European attraction to remote and exotic Asian countries in the seventeenth and eighteenth centuries arose in the wake of the colonization of India. In the first half of the nineteenth century, the Orientalist trend in French literature waned somewhat, only to be revived and further exploited by mid-nineteenthcentury writers. One of the important historical events that stimulated this revival was the opening of Japan 10 the West by the American naval officer Matthew C. Perry in 1852. The mysterious "Land of the Rising Sun" spurred the imagination of European artists, who began stylizing Japanese art. Nipponizing tendencies soon became pronounced in French art and literature, a style French art critic Philippe Burty labeled japonisme in 1872. Interest in Japan in turn accelerated a creative exploration of China, India, and other Eastern countries. Travelers brought back exquisite artwork, which was displayed and sold in all major European cities. An art gallery called La porte chinoise was quickly opened in 1862 in Paris to capitalize on the rising enchantment with Asia, and the shop counted many Bohemian notables among its customers. European Universal Exhibitions, especially those held in 1851, 1855, and 1867. featured multiple Chinese and Japanese exhibits. All these activities give credence to the observation of François Coppée, one of the first reviewers of Le livere de jade, that "the taste for chinoiserie, which until recently was accessible only to the most opulent collectors, is now quite vulgarized in France" (4).

The Parnassians contributed to the cultivation of this taste for chinoiserie. Parnasse was a loosely gathered poetic movement that emerged in the second half of the nineteenth century, deriving its name from the Parnass contemporain, a poetic almanac that was issued three times, in 1866,1869 , and 1876 . While the Parnasse contemporain included a wide range of styles and thematic content, in general members of the movement shared a purely aestheticist (art for art's sake) agenda, an emphasis on verbal craftsmanship (as opposed to the primacy of inspiration advocated by the forerunning Romantic school), an impassive and impersonal quality in their verse, and a tendency to enrich poetry with the effects of the visual arts, with a resulting penchant for descriptiveness. In opposition to Romanticism, Parnasse drew on neoclassical sensibilities, as did the Academic style in contemporary painting exemplified by Théodore Chassériau, Gustave Moreau, and others. Furthermore, while both Romantic and Parnassian poets shared an interest in exoticism and Orientalism, the Romantics used the East primarily as a generalized, lavish background, whereas the Parnassians aspired to an authentic restoration of Oriental cultures, often employing nearly archeological precision.

The leader of Parnasse, Théophile Gautier, was, according to William Schwartz, "the first imaginative French writer in the nineteenth century to discover the artistic possibilities of this [Chinese] material" (17). In Gautier's poem "Chinoiserie" (from Póésies diverses, 1833-38) the lyric hero paints an exquisite verbal portrait of his beloved, who lives in a porcelain tower and demonstrates all the conventional features of a Chinese beauty: 
Ce n'est pas vous, madame, que j'aime, Ni vous non plus, Juliette, ni vous, Ophélia, ni Béatrix, ni même Laure la blonde avec ses grands yeux doux. Celle que j'aime, à présent, est en Chine, Elle demeure avec ses vieux parents, Dans une tour de porcelaine fine, Au fleuve Jaune, où sont les cormorants.

Elle a des yeux retroussés vers les tempes, Un pied petit à tenir dans la main, Le teint plus clair que le cuivre des lampes, Les ongles longs et rougis de carmin.

Par son treillis elle passe sa tête,

Que l'hirondelle, en volant, vient toucher, Et chaque soir, aussi bien qu'un poète Chante le saule et la fleur de pêcher. (Poésies complètes 1.329)
It is not you, no, madam, whom I love, Nor you either, Juliet, not you, Ophelia, nor Beatrice, nor that dove, Fair-haired Laura with the big eyes; No.

She is in China whom I love just now; She lives at home and cares for her old parents; From a tower of porcelain she leans her brow, By the Yellow River, where haunt the cormorants.

She has upward-slanting eyes, a foot to hold In your hand-that small; the colour shed By lamps is less clear than her coppery gold; And her long nails are stained with carmine red.

From her trellis she leans out so far That the dipping swallows are within her reach, And like a poet, to the evening star She sings the willow and the flowering peach. (trans. A.J.M. Smith, Poems from France 87-88)

Similarly, the young woman in "Sonnet" (from Poésies diverses, 1833-38) is "full of Chinese grace," and her tender scent is reminiscent of tea:

Ses mouvements sont pleins d'une grâce chinoise, Her movements are full of Chinese grace, Et près d'elle on respire autour de sa beauté And those near her inhale around her beauty Quelque chose de doux comme l'odeur du thé. Something as sweet as tea's aroma. (Poésies complètes 1.330 )

Gautier included another sonnet, "La Marguerite," in the 1866 first edition of Parnasse contemporain, in which he mentions the great eighth-century Chinese poet Li-Tai-Peh, whose poems his daughter Judith was rendering into rhythmic prose around the same time. In 1846 Gautier published a Chinese novella, Le pavillion sur l'eau (Pavilion on the Water), based on three tales ("L'Ombre dans l'eau," "Trois étages consacrés," and "Deux cousines") from Contes chinois (1827), a collection of Chinese tales by pioneer Sinologist and first professor of Chinese at the Collège de France Abel Rémusat.' Other, more subtle, allusions to China are scattered throughout Gautier's oeuvre. He addressed various aspects of Chinese culture in his numerous essays for La Presse and Moniteur and wrote accounts of Asian exhibits at the Universal Exhibitions of 1851, 1855, and 1867.

Théophile Gautier's passion for China proved contagious for his fellow Parnassians and those who shared their aesthetic sensibilities. Mid-nineteenthcentury Europeans perceived China largely through its tea and porcelain, probably because both were among the most common goods imported from that distant land. Poets frequently evoked the intricate designs on Chinese porcelain cups. For example, in a short poem entitled "Thé" ("Tea," 1876). Théodore de Banville implores a lady to pour him some tea into "the charming Chinese cup" and proceeds to describe the pictures of fish, monsters, and a woman depicted on the porcelain. In his poem "Epilogue," published in the 1866 issue of Parnasse contemporain, Stephane Mallarmé expresses a desire to imitate a Chinese artist, pure of heart and completely devoted to mastering his delicate art of cup decoration:

\footnotetext{
"For a detailed discussion of Cautier's creative interpretation of his subtexts, sec Henri David.
} 
Je veux .

Imiter le Chinois au coeur limpide et fin De qui l'extase pure est de peindre la fin Sur ses tasses de neige à la lune ravie D'une bizarre fleur qu'il a senti, enfant, Au filigrane bleu de l'âme se greffant. Et, la mort telle avec le seul rêve du sage, Serein, je vais choisir un jeune paysage Que je peindrais encore sur les tasses, distrait. (Le Parnasse contemporain 170)

\author{
I want ... \\ To imitate the Chinese, with his heart so limpid and fine, \\ For whom purest pleasure is to paint \\ On his cups of moonlit snow \\ The end of a strange bud that perfumes his life, \\ The transparent flower he felt when a child, \\ Cleaving to the blue filigree of his soul. \\ And, such a death with the wise man's only dream, \\ Serene I will choose a youthful landscape \\ To paint again on the cups, distracted.
}

In the vein of Gautier, Jose-Maria de Heredia pictures a young Chinese beauty, endowed with all the stereotypical features (a microscopic foot, elongated eyes, a parasol, and a fan), in his early sonnet "L'Ecran" ("The Screen," 1868), published in Gautier's printing venture, the journal L'Artiste. Claudius Popelin's sonnet "Chinoiserie" (1875), which shares the title with Gautier's poem of 1835 , features yet more familiar images, such as a young Chinese girl eating rice with chopsticks, a mandarin, and lacquered furniture. In 1859 Parnassian Louis Bouilhet contributed "Tou-Tsong," "Le barbier de Pékin," and "Dieu de la porcelaine" to the chinoiserie fashion. "Tou-Tsong" features a mandarin wearing embroidered slippers and a pointed hat, smoking opium, walking with dignity under a parasol, and conversing with his friends in a pavilion lit with painted lanterns.

Clearly, then, by the middle of the 1860 s certain Chinese topoi had emerged in the poetry composed in Parnassian circles. Chinese culture was assimilated as a limited number of stock images inspired more by the iconography of art objects available for European vicwing than by scholarly essays or travelogues. Evaluating Chinese exhibits at the Lniversal Exhibition of 1867 in his article "Chinese and Russians at the Universal Exhibition in Paris" ("Chinois et Russes à l'Exposition universelle de Paris"), published in Le moniteur universel, Gautier admitted that prior to China's wide exposure in the West, the European perception of its culture was circumscribed by a set of clichés. Gautier then enumerated the common images that contributed to a "local color" effect-a catalogue that reads like a series of quotations from Parnassian poems on Chinese themes: "pot-bellied men with slanted eves and a complacent smile, who shake their heads when the wind stirs the bells at the roof-corners, upturned like the end of a slipper, . . porcelain women staggering on their little feet, and ... corpulent mandarins celebrating a peach flower or china-asters while drinking cups of Souchon, as one might see in a screen painting" (4).

It was only natural that Judith Gautier turned to Chinese culture carly in her youth, as she was exposed to the Parnassian adoration for and creative exploration of the Far East both through her father and her husband, Catulle Mendès, a dedicated disciple of Théophile Gautier. Her father provided the initial impetus, when, in 1863, he invited a Chinese acquaintance, Tin-Tun-Ling, to give Judith and her sister Estelle Chinese lessons. Tin-Tun-Ling had been brought to France by the missionary and interpreter at the French embassy in China, J.M. Callery, to compile a French-Chinese dictionary. After Callery's sudden demise, his protégé was left without support or guidance in a country whose language he could barely speak. By chance Tin-Tun-Ling met one of Gautier's friends, who introduced him to the writer. Initially. Gautier raised money to send the stranded Chinese 
home, but Tin-Tun-Ling was afraid to return lest his fellow Chinese behead him (perhaps for his participation in a political conspiracy). Offering him a position as his daughters' language instructor, then, must have seemed to (xatutier an easy way out of a complicaled situation. Tin-Tun-Ling became a close friend of the Gautiers and a regular guest at their dinner table. Judith was captivated by the exotic appeal of the Chinese language and soon asked her teacher, who himself composed verse, to introduce her to the treasure trove of Chinesc poetry, which she was eager to render in French. Judith and Tin-Tun-Ling begin to frequent the National Library on Richelieu street (at the time the only place where they could lay their hands on rare Chinese books) and copied many classical poems by hand until the library granted them the right to check out the books they read so avidly. At home, they studied these texts in detail, and Judith subsequently translated some of them into rhythmic French prose. Her father approved of his daughter's efforts and occasionally versified her prose translations (Camacho 30-32).

When Judith's translations came out as an elegant book, entitled The Book of Jade, they marked the debut of a successful literary career. Although married to Catulle Mendès by the time of publication, Judith chose neither her married nor her maiden name to adorn the cover of her first book, but signed as Judith Walter, "Walter" being German for "Gauticr" or "the lord of the woods." Rémy Gourmont translates the wo Chinese ideograms on the cover of the book as "jade brushsaying," which he interprets as "To speak or to say with a brush is to write" (12), underscoring the visual, painterly aspect of Judith's poems-a characteristic in keeping with the rich pictorial possibilities of Chincse rerse. Br a lucky coincidence, The Book of Jade came out when the splendors of the Asian art displayed in the Universal Exhibition of 1867 occupied the minds of the Parisian cultural elite. Not surprisingly, the reception of the book was en thusiastic.

While Judith's book was one of the pioneering collections of Chinese verse in French translation, it was not the first. Five years prior to the publication of $T$ he Book of Jade, Marquis I'Hervey-Saint-Denys had put out a scholarly edition of Tang Dynastv (618-907 C.E.) poctry, Poésies de l'époque des Thong (1862). SaintDenys provicled an essay on Chinese poetic art, biographies of each poet, and extensive commentary for each text, but the translation failed to display the significant poetic qualities that might have attracted the nonspecialist reader. In this respect, Saint-Denys was continuing the earlier European tendency to regard Chinese verse as a mere source of information about Chinese customs, while ignoring its aesthetic value. As Muriel Détrie states in her article "Translation and Reception of Chinese Poetry in the West," this tradition of selecting poetic texts based on their documentary value and rendering them "without the slightest concern about meter, rhythm, rhyme, euphony, and so on" (48) goes back to the earliest European translations from Chinese, composed by Jesuits in the eighteenth century. As opposed to Saint-Denys, Gautier included no commentary in her book, focusing instead on the elaboration of poetic form and covering a range of poets beyond the Tang Dynasty.

For her project, Judith selected poems by the most acclaimed classical Chinese authors. supplementing them with verse by a few modern writers. including her 
teacher Tin-Tun-Ling, to whom The Book of Jade was dedicated. She divided the book into seven cycles: "Lovers," "The Moon," "Autumn," "Travelers," "Wine," "War," and "Poets." Striving to convey the meaning and sentiment of the original texts as best she could, Judith opted for rhythmic prose, reminiscent of the poem in prose, a genre made popular by Charles Baudelaire's Petits poèmes en prose. For the most part, the texts were short, capturing a thought or a feeling in just a few lines, through delicate allusions rather than direct evocation. Praising Judith's refined style and exquisite language, some contemporarics compared her to her celebrated father. Anatole France, for instance, underscored both the continuity and originality of Judith's writing: "She had a style of her own, a style that was serene and sure, rich and placid, like that of Théophile Gautier, less robust, less solid, but infinitcly fluid and light" (Richardson 58). Her style definitely demonstrated the important Parnassian quality of impassivity, which also best conveyed the mood of the originals, as "Chinese poetry rarely takes for its subject violent feelings, but rather delicate sentimen ts, the evocation barely sketched. Refinement of the language and surprising imagery are ways to evoke the inexpressible. A couple of lines suffice to convey the heart's melancholy, the destiny's cruelty, and the Oriental resignation" (Camacho 49).

Despite the accolades Judith received from her contemporaries, many scholars have pointed out that she repeatedly violated the strict form and meaning of the texts she translated. Most of these violations were due to her lack of familiarity with Chinese literary canons, insufficient knowledge of the language, the differences between Chinese and French systems of versification, and the contrast between Asian and European discourse at large. When confronted with technical difficulties, Gautier frequently took refuge in her own cultural milieu, from which she borrowed themes and forms of expression, as well as conventions in the representation of China. To some degree, her book smacks of dilettantism, and, in Fusako Hamao's words, Judith created chinoiserie rather than literally translated Chinese verse (83).

On the most superficial level, the names of many Chinese poets were misspelled, although such mistakes are understandable given that no standard system of transliteration of Chinese existed at the time. Furthermore, many poems were ascribed to the wrong authors. (Gautier corrected some of these mistakes in the 1902 edition of The Book of Jade.) More importantly, Gautier altered the impersonal tone of Chinese verse, inundating her translations with personal pronouns. A certain degree of grammatical personalization is inevitable in French, but Gautier could have avoided further concretization had she not inserted modifiers, especially color epithets, and other embellishments absent from the original. As a result, Gautier's translations at times collide with the spirit of Chinese poetry, which is elliptical in character and allows for multiple interpretations. Chinese poetic discourse favors syntagmatic relations between its constituent elements, which, as Détrie puts it, unfold before the reader's view as a simple succession of images ("Le Livre" 316). Judith, on the other hand, approaches the texts from an analytical standpoint, imposing her own logic on the presentation of images.

Conversely, Gautier ignores the allusive nature of Chinese poems, which al- 
ways recall a particular historical event or personage by mentioning places and names. In her translations, she routinely substituted generic words for proper names, avoiding historical, geographical, and cultural allusions that would be incomprehensible to a Western reader and making the texts more general. Finally, Gautier increases the romantic tonality in her translations by dwelling on emotions, which are customarily veiled or merely indirectlv suggested in Chinese. As Détrie points out, by opening her collection with a cycle dedicated to love, a sentiment much less prominent than friendship in ('hinese verse, Gautier deferred to the demands of French taste ("Le Liore" 313). Thus Gautier violated many conventions, unconsciously or not, and Gumilev's translations, twice removed from their Chinese originals, both reproduced their French sourcescomplete with faults and inconsistencies-and altered them to promote an independent poetic agenda.

Nikolai Gumilev's The Porcelain Pavilion: Chinese Verse consists of two parts, entitled "China" and "Indochina." In this essay, I am concerned with the eleven poems from the first part, which are all translations into Russian from The Book of Jade.' In many respects. Gumilev's book can be regarded as an independent work in its own right. Although Gumilev painstakingly conserves the theme, plot, and mood of each piece, he substitutes verse for the rhythmic prose of the original, changes the structure of the book by eliminating Gautier's "cycle" divisions, and alters the selection of texts. The title of the first poem of the collection also becomes the title for the entire book and perhaps reveals Gumilev's primary thematic focus, one which does not necessarily coincide with that of Judith Gautier.

"The Porcelain Pavilion" is presented as a translation of one of the most celebrated Tang poets, Li Po (700-762), also known as Li Tai Peh or Li Tai Po. During his restless, eccentric life, Li Po experienced fame, success, and false accusations. When his talents were recognized by the emperor, he received a post at the Hanlin Academy, but soon thereafter court intrigues led to a fall from favor and exile. Li Po was a vagabond, drinker, and, by some accounts, a Taoist, which explains the "seeming casualness toward wealth and fame" (Sunflower Splendor 553) evident in his verse. He spent years in remote mountainous retreats, seeking a kev to the ultimate truth, the secret of immortality, and the mysteries of nature. According to popular legend, he died by drowning in the river while intoxicated, trying to kiss the Moon's reflection in the water. Li Po's hallmark themes were wine, the joys of friendship, poetic composition, and contemplation of nature. We find all of these subjects in Gautier's and Gumilev's "The Porcelain Pavilion":

Au milieu du petit lac artificiel

s'élève un pavillon de porcelaine

Sredi iskusstvennogo ozera

Podnialsia pavil'on farforovyi,

verte et blanche; on y arrive par

Tigrinoiu spinoiu vygnutyi,

un pont de jade qui se voûte

Most iashmovyi k nemu vedet.

comme le dos d'un tigre.

The first, 1918, edition contained only ten poems. "Serdte radosmo, serdise krvlato" ("The Heart Is (ilad, the Heart Is Winged") was included only in subsequent editions. 
Dans ce pavillon quelques amis vêtus de robes claires boivent ensemble des tasses de vin tiède. Ils causent gaiement ou tracent des vers en repoussant leurs chapeaux en arrière, en relevant un peu leurs manches.

Et, dans le lac où le petit pont renversé semble un croissant de jade, quelques amis vêtus de robes claires boivent, la tête en bas, dans un pavillon de porcelaine. (J. Gautier 113-14)

(In the middle of a small artificial lake rises a green and white porcelain pavilion; one gets there by a jade bridge curved like a tiger.

In this pavilion, several friends dressed in light clothing are drinking cups of warm wine together.

They are talking gaily or jotting down their verse,

cocking back their hats or rolling their sleeves a little.

And in the lake, where the little bridge turned upside down appears as a jade crescent, several friends dressed in light clothing are drinking, lowering their heads, in the porcelain pavilion.)
I v etom pavil'one neskol'ko Druzei, odetykh v plat'ia svetlye, Iz chash, raspisannykh drakonami, P'iut podogretoe vino.

To razgovarivaiut veselo, A to stikhi svoi zapisyvaiut, Zalamyvaia shliapy zheltye, Zasuchivaia rukava.

I iasno vidno $v$ chistom ozere-

Most vognutyi, kak mesiats iashmovyi, I neskol'ko druzei za chashami, Povernutykh vniz golovoi. (Stikhotvoreniia 273)

(Risen from the artificial lake, The jasper bridge Curved like a tiger's spine Moves our direction.

And in that pavilion several

Friends in light clothing Drink mulled wine

From cups painted with dragon.

Now conversing pleasantly,
Or jotting out their poems,
Cocking their yellow caps,
Rolling up their sleeves.
It's clear in the clear lake
The concave bridge like a jasper moon,
With several friends of the cup
Turned upside down.
[Twentieth-Century Russian Poetry 74-75])

Now conversing pleasantly, Or jotting out their poems, Cocking their yellow caps, Rolling up their sleeves. With several friends of the cup

[Twentieth-Century Russian Poetry 74-75])

Apparently, Judith Gautier's rendition of Li Po's poem attracted Gumilev due to its metapoetic content, expressing the ideals of art for art's sake and leisurely creativity, themes that resonated deeply with the anti-utilitarian views espoused in Acmeist circles. From this perspective, a model poet has forsaken worldly ambitions and composes serenely for the sake of pure aesthetic and emotional enjoyment, savoring wine among good companions. Just as the process of poetic composition is best when carefree and pleasurable, so its end result must be simply beautiful. These same thoughts spoke volumes for Gautier and Gumilev, who were firmly against transforming art into a forum for social, political, or religious issues.

In 1865, while Judith was still working on her translation, her father invoked $\mathrm{Li}$ Tai Peh in the sonnet "La Marguerite," in which the beauty of the flowers before the poet is sufficient to engender poetic inspiration:

Les poètes chinois, épris des anciens rites,

Ainsi que Li-Tai-Péi, quand il faisait des vers,

Mettent sur leur pupitre un pot de marguerites

Dans leurs disques montrant l'or de leur

coeurs ouverts.

(Th. Gautier, Poésies complètes 238)
Chinese poets, enamoured with old customs, As did Li Tai Peh when composing his verse, Place a pot of china asters on their lecterns, In their disks showing the gold of their open hearts. 
Elements of the topoi from "The Porcelain Pavilion" are also found in Theophile Gautier's earlier Chinese tale, Le pavillon surl'eau (The Pavilion on the Water, 1846), in which two neighbors share a pond and build exquisite parilions, each on his own side. When their friendship turns sour, they erect a wall in the middle of the pond so that neither can see the other's property. Now each can only glimpse the reflection of his neighbor's pavilion in the water of the pond, and this is how their children see each other for the first time, standing on the balconies of their respective pavilions and admiring the image of the other in the water. The son of one neighbor falls in love with the reflection of the other's daughter, and this sentiment eventually leads to the two families' reconciliation. Gautier ends his story with the formula, "Happiness is often but a shadow in the water." In this elegant tale, Gautier recounts how in the early days of their friendship the neighbors spent peaceful autumnal evenings among fellow poets, jotting down in black ink improvisations on the beauty of china asters (reines-marguerites) and sipping wine from small cups. Henri David points out that Gauticr wanders from his subtext, Rémusat's L'ombre surl'eau (The Shadow on the Water), to describe in minute detail the porcelain tiles of the pavilions and their interior walls, which are adorned with quotations from Chinese poets, including Li Po. These deviations, however, were in line with the Parnassian inclination toward exhaustive descriptions of artifacts in their verse and contributed to the creation of "local color," as Chinese masters were equally prone to the verbal rendering of plastic art (David 154-57).

While the imagery in Judith's poem appears to derive from her father's prose tale, it is a far cry from Li Po's text. In fact, scholars considered this translation a case of incorrect attribution until Fusako Hamao discovered Li Po's poem "A Party at Mr. Tac's Pavilion" after a painstaking examination of the Chinese collection acquired by Bibliothèque Impériale before 1867 - the corpus of texts likely available to Judith. Hamao printed her literal translation of this Chinese poem in her article "The Sources of the Texts in Mahler's Lird von der Erde":

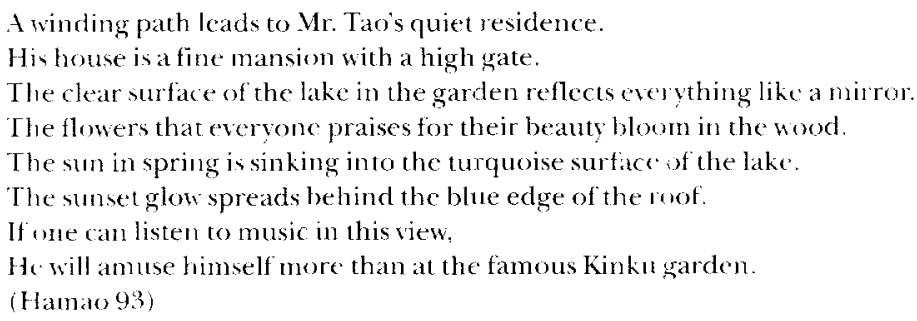

Surprisingly, the Chinese text contains no references to porcelain, the artificiality of the lake, the jade bridge, friends, or their garments. These elements apparently sprang partly from Gautier's imagination and partly from her mistranslation. As Hamao explains, Gautier must have misinterpreted the last four characters of the Chinese title as "the porcelain pavilion" instead of "Mr. Tao's pavilion", a plausible mistake since every Chinese character is polysemantic, and specific meaning is established primarily through context (92). Judith's misreading seems even more likely if we recall the conventional references to porcelain in nineteenthcentury European texts about China-for example, the Parnassian verse quoted above. Another factor must have been the construction of a porcelain pavilion, 
reportedly an imitation of the Summer Palace near Beijing, in the Chinese garden created for the 1867 Exposition Universelle in Paris (Hamao 94). The poem, then, is at clear example of how stercotypes from the translator's immediate cultural milieu can interfere with clarity of understanding.

Hamao also indicates that Gautier used commentary from a footnote to the poem by Wang-Khi. who described the festivities at the Kinku Garden where people drank, composed verse, and played music (92). In her usual manner, Gautier eliminated the proper name (Kinku) from her translation and freely elaborated on the festive scene. She colors the porcelain pavilion in green and white and connects it to the shore by a jade bridge. Jade is an important stone for the Chinese: symbolizing longevity, it was used for ritual purposes, and some ancient burial shrouds were even made entirely of jade, apparently to ensure eternal life for the deceased. Along with porcelain vases and lacquer items, jade articles inundated the European market in the nineteenth century, becoming a standard item of Chinese paraphernalia.

In translating Gautier's poem, Gumilev took even greater liberties, introducing additional pictorial elements better to simulate Chinese culture. His "The Porcelain Pavilion" contains several details absent from Gautier's text: the poets' hats are "yellow" (in Russian Modernist vocabulary, yellow was firmly associated with Asia), and the wine cups are "painted with dragons." The dragon's most obvious connotation is its symbolic association with China, as numerous Chinese objects of art were decorated with images of this fantastic creature, worshiped as the lord of the sea. However, a different, less evident meaning of the dragon is provided in another poem in The Book of Jade, "A Poet Gazes at the Moon" ("Un poëte regarde la lune," after Tang-Jo-Su), which Gumilev programmatically entitled "The Poet." In this text, the dragon becomes a metaphor for the poet:

Vo vzory poetov, zabyvshikh pro zhenshchin, Otradno smotret'sia lune,

Kak v polnye bleska cheshui drakonov,

Sviashchennykh poetov morei.

(Stikhotvoreniia 277 )
Into the eyes of poets now oblivious of women Joyfully gazes the moon,

Gazes as if into the shiny scales of dragons, those holy poets of the seas.

The image of the dragon thus helps Gumilev highlight what he perceives to be the main theme of the opening piece-the theme of poetry, poets, and creativity.

That these dragons are painted on cups also emphasizes the artist's power over his material. The diminutive size of the visual referent. whose real dimensions would have been frightening, makes the reader aware of the limits the artist has imposed on the world he portrays. This theme was explored by several poets in Parnassian and Acmeist circles. In Banville's poem "Thé" ("Tea") the sinister chimeras depicted on a Chinese cup are chained and rendered harmless: "J'aime la folle cruauté/Des chimères qu'on apprivoise" ("I like the wanton cruelty/Of the chimeras one chains up," trans. Barbara Howes, Poems from France 105). Mikhail Kuzmin developed similar motifs in his poem "Fudzii v bliudechke" i"Fujiyama in a Saucer," 1917). Kuzmin's Apollon manifesto, "On Beautiful Clarity." like most Acmeist manifestos, advocates the "poetry of objects" as opposed to a dreamy, metaphorical style. His poem presents in parallel fashion an awesome and threatening Japanese volcano as a miniature image on a porcelain saucer: 
Skvoz' chainyi dym ia vizhu goru Fuzii, Na zheltom nebe zolotoi vulkan. Kak bliudechko prirodu stranno uzit! No novyi trepet melkoi riab'iu dan. Kak oblakov prodol'nykh pautinki Pronzaet solntse s murav'inyi glaz, A ptitsy-ryby, chernye chainki, Chertiat lazuri zyblemyi topaz! Vesennii mir vmestilsia v malom mire: Zapakhnut mindali, zatrubit rog, I ves' zaliv, khot' bud' on vdvoe shire, Farforovyi obnimet obodok.

(Kuzmin 35)
Through steam from tea I see Mount Fujiyama, A gold volcano against yellow sky.

A saucer contracts Nature very strangely:

Ripples give new impressions to the eye!

See how the oblong, cobweb clouds are calmly Pierced by a sun the size of an ant's head. And how black bits of tea, like birds or fish, Form lines where that blue topaz sky is spread! The world of spring is in this microcosm:

The horn will sound, the almond trees will bloom, The porcelain rim will hold the whole bay in it; With twice as much water, there'd still be room. (Modern Russian Poetry 221)

Kuzmin sees in the saucer a compressed representation of the entire natural world, replete with mountains, clouds, the sun, birds, fish, and plants, a miniature universe over which the artist can establish his supreme authority.

Both French Parnassian poets and their Russian Acmeist followers favored artful, miniature representations of a reality that remains entirely under man's control, in opposition to the infinite, sublime-and so, potentially menacinguniverse of the Romantics and Symbolists, who preceded the two movements, respectively. This primacy of the man-made over the natural becomes the central theme of Gumilev's poem "Priroda" ("Nature," an adaptation of Gautier's "Un poëte rit dans sons bateau," after Ouan-Tié). Gumilev chooses the form of traditional Chinese couplets (absent from Gautier's translation), in which the two lines often contain antithetical ideas that nevertheless complement each other and contribute to the reconstruction of a complete picture of the world. ${ }^{8}$ Gumilev's poem consists of four couplets, in which natural phenomena are systematically juxtaposed against artificial creations. The poet observes that nature copies manmade shapes, and concludes that natural forms derive from man-made images.

Spokoino malen'koe ozero,

Kak chashka, polnaia vodoi.

Bambuk sovsem pokhozh na khizhiny,

Derev'ia-slovno more krysh.

A skaly ostrye, kak pagody,

Voznosiatsia sredi tsvetov.

Mne dumat' veselo, chto vechnaia

Priroda uchitsia u nas.

(Gumilev, Stikhotvoreniia 274)

\author{
The little lake is quiet, motionless \\ As water in a brimming bowl. \\ Bamboos resemble huts undoubtedly, \\ The trees are but a sea of roofs. \\ And like pagodas rocks jut spikily \\ Above the shrubs and flowers there. \\ It gladdens me to find eternal Nature \\ Apprenticing herself to us. \\ (Two Centuries of Russian Verse 143)
}

Both Judith Gautier and Gumilev inherited the Parnassian cult of the artificial, as well as its contempt for the slavish imitation of nature in art. Because this view was also deeply rooted in traditional Chinese poetics, with its "focus . . on the productive mechanics of a poem" (Owen 42), Chinese poetry in effect confirmed their own aesthetic views. Thus, Stephen Owen's account of traditional Chinese poetics might just as easily stand as an account of the aesthetics underlying The Book of Jade and The Porcelain Pavilion:

\footnotetext{
"For a discission of couplets in Chinese verse see Owen (91 96). As Farl Sampson indicates, Gumilev had an "active interest in Oriental poctry" (32), collected anthologies and studies of Oriental verse, and was therefore surely aware of the poetic possibilities of the Chinesc couplet.
} 
The act of uriting a poem is no innocent and spontaneous production of a correlative for expericnce. The writing has its own ends. which lie entirely outside the experience. A poem in directed to a reader: words must be given form according to the laws of literature and representation, not according to the laws of the physical universe ... The poem is ... an artificed construct. (40)

Furthermore, if Chinese metapoetic riews occupy a significant place in The Book of Jade, they acquire an absolutely primary position in Gumilev's book. Indeed, the title for the entire collection, borrowed from the poem by Li Po, which inaugurates the cycle and dwells on the mechanism of the creative process, indicates that Gumilev regarded the theme of poetic art as central to his book. From this perspective, his selection of texts from among Gautier's translations is also significant. Most of them appear to touch upon art, poets, and creativity, with more than half of the eleven poems unequivocally metapoetic. The central image of the collection, the "porcelain pavilion," becomes a symbol analogous to the ivory tower - a world of aesthetic delights, shielded from any intrusion of coarse reality.

The poem "The Porcelain Pavilion" establishes a particular topoi also deployed in other poems of the cycle. The central concept is that poetic inspiration requires a leisurely, meditative state of mind, a company of good friends and fellow poets, mulled wine, and serene contemplation of nature and reflections in the water. In the second poem of Gumilev's cycle, "Luna na more" ("The Moonlight in the Sea," an adaptation of Gautier's "Le claire de lune dans la mer," after Li-SuTchong), several friends are drinking hot wine on a boat as they watch the reflection of moonlight on the sea and the whimsical shapes of passing clouds. While Gautier simply and sparsely recounts that the friendly gathering took place, Gumilev deploys key words that establish associations with other poems in the cycle dealing with the creative process: he emphasizes that the friends are drinking in a "leisurely" manner (ne toropias") and that they watch the clouds "dreamily" (mechtatel'no). Leisure and dreaminess are again emphasized as conditions for creativity. Ultimately, the creative impulse spurs everyone to see the clouds in a different light: as a parade of the emperor's wives, as swans, and even as pious souls on their way to paradise (the last image is Gumilev's own addition). Although the French text does not mention that the friends assembled in the boat are poets, Gumilev creates, by adding a few essential words, an evocative scene conducive to poetic inspiration.

La pleine Lune vient de sortir de l'eau. La mer ressemble à un grand plateau d'argent. Sur un bateau quelques amis boivent des tasses de vin.

En regardant les petits nuages qui se balancent sur la montagne, éclairés par la Lune,

Quelques-uns disent que ce sont les femmes de l'Empereur qui se promènent vêtues de blanc;

Et d'autres prétendent que c'est une nuée de cygne.

(J. Gautier 45-46)

(The sea is like a great platter of silver. On a boat, a few friends are drinking cups
Luna uzhe pokinula utesy,

Prozrachnym more zolotom polno, I p'iut druz'ia na lodke ostronosoi, Ne toropias', goriachee vino. Smotria, kak tuchi legkie prokhodiat Skvoz' lunnyi stolb, chto v more otrazhen, Odni iz nikh mechtatel'no nakhodiat, Chto eto poezd bogdykhanskikh zhen; Drugie veriat-eto $\mathrm{k}$ roshcham raia Ukhodiat teni nabozhnykh liudei; A tret'i s nimi sporiat, utverzhdaia, Chto eto karavany lebedei.

(Gumilev, Stikhotvoreniia 273-74)

(The Moon has already left the cliffs, The sea is filled with transparent gold, 
of wine.

And as they look at the little clouds that balance themselves on the mountain lighted by the moon:-

Some say that they are the wives of the Emperor that are wandering above, clad in white,

And others pretend that they see a cloud of swans.

[From the French 97])
In a sharp-prowed boat friends are drinking Hot wine, not hurrying at all.

Watching light clouds that are passing through the moonlight column, reflected in the sea, some of them see it dreamily As a train of the Khan's wives;

Others believe that these are god-fearing people's souls on their way to the groves of paradise;

And yet others argue with them, claiming that these are flocks of swans.)

Gumilev included the same text in his unfinished long narrative poem "V Kitae" ("In China," 1917-18), which he conceived around the same time as The Porcelain Pavilion. Extant fragments from this poem were published in 1986 by YMCAPRESS. According to the editors, Gumilev intended to write a poem for children in 12 parts (Gumilev, Neizdannoe 217). As one can judge from the 38 surviving quatrains, the main characters of this poem are a boy and a girl, Ten-wei and Laitse, children of two literati mandarins and neighbors. Ten-wei recites Li-SuTchong's poem after a festive meal of 170 dishes at the house of Lai-tse's father, who is playing host to a distinguished guest - an ambassador from a distant province. Gumilev carefully reconstructs the social context, describing the sophisticated ceremony of entertaining honorable guests. As the editors of Sunflower Splendor point out, in China traditionally "verses were recited from memory at state functions by officials in the course of diplomatic receptions" (xvi).

In their translations of another poem by Li Po, "A Song on the River" ("Chanson sur le fleuve," a title Gumilev translated as "Happiness"), both Gautier and Gumilev concentrate on the Epicurean motif. The lyrical voice proclaims that a flute of jade, a light boat, wine, and a pretty young lady are all he needs to be like an immortal "sky spirit" (a poet, perhaps). In "Poet" (an adaptation of Gautier's "Un poëte regarde la lune," her translation of a poem by Tang-Jo-Su), however, the lyric persona admits that he is enticed more by the moon than by a mortal woman. The poet is withdrawn from the world of human passions and absorbed by the divine beauty of the nocturnal sky. In contrast to Gautier's rhythmic prose, Gumilev's translation is again arranged in couplets:

De mon jardin j'entends chanter une femme, mais malgré moi je regarde la Lune.

Je n'ai jamais pensé à rencontrer la femme qui chante dans le jardin voisin; mon regard suit toujours la Lune dans le ciel. Je crois que la Lune me regarde aussi, car un long rayon d'argent arrive jusqu'à mes yeux.

Les chauves-souris le traversent de temps en temps et me font brusquement baisser les paupières; mais lorsque je les relève, je vois le regard d'argent toujours dardé sur moi.
Ia slyshal iz sada, kak zhenshchina pela, No ia, ia smotrel na lunu.

I ia nikogda o pevitse ne dumal, Lunu v oblakakh poliubiv.

Ne vovse chuzhoi ia prekrasnoi bogine: Otvetnyi ia chuvstvuiu vzgliad.

Ni vetvi derev, ni letuchie myshi Ne skroiut menia ot nego.

Vo vzory poetov, zabyvshikh pro zhenshchin, 
La Lune se mire dans les yeux des poëtes comme dans les écailles brillantes des dragons, ces poëtes de la mer. (J. Gautier 49-50)

(From my garden I hear a woman singing, but in spite of her I gaze on the moon. I have never thought of meeting the woman who sings in the neighboring garden; my gaze ever follows the moon in the heaven. I believe that the moon looks at me too, for a long silver ray penetrates to my eyes. The bats cross it ever and anon, and oblige me suddenly to lower my lids; but when I lift them again, I still see the silver gleam darted upon me.

The Moon mirrors herself in the eyes of poets as in the brilliant scales of the dragons, those poets of the sea. [From the French 90])
Otradno smotret'sia lune.

Kak v polnye bleska cheshui drakonov, Sviashchennykh poetov morei (Gumilev, Stikhotvoreniia 277)

(From my garden, I heard a woman sing, But I was watching the moon.

And I've never thought of the singer, As I fell in love with the moon in the sky.

I'm not a total stranger to the gorgeous goddess,

I feel her gaze upon me.

Neither branches of the tree nor bats Will conceal it from me.

The Moon rejoices in looking into the eyes of poets who have forgotten women,

As into shimmering scales of dragons, Those holy poets of the sea.)

The moon's romantic image appears again in a translation from Sao Nan, "A Young Poet Thinks of His Beloved, Who Lives on the Opposite Side of the River" ("Un jeune poëte pense à sa bien-aimée, qui habite de l'autre côté du fleuve," which Gumilev entitled "Soedinenie" ["Union"]). In this poem a young poet contemplates the reflection of the moon in a lake, and the union of moonlight and water makes him think of the harmony he would like to achieve in a human relationship with his distant beloved. Here nature is endowed with human emotions (the moon is "in love" and this love renders the water "happy"), and, through the use of pathetic fallacy, it mirrors the poet's state of mind.

The motifs of love, the moon, and an earthly woman unite three poems from The Porcelain Pavilion, "Soedinenie" ("Union"), "Poet" ("Poet"), and "Dom" ("House") into a mini-cycle. In "Union," the moon promises a sort of happiness that humans cannot achieve in their relationships. In "Poet," the young man rejects a woman and pursues the moon, which embodies his romantic ideal. Finally, in "House" (an adaptation of Gautier's "La maison dans le coeur" [The House in the Heart] translated from another great classical Chinese poet, $\mathrm{Tu} \mathrm{Fu}$ ), a woman replaces the image of the moon in the eyes of a devastated lyrical hero. Reflection again plays a crucial role here, as the woman's face in the water revives feeling and hope in the poet's heart:

Les flammes cruelles ont dévoré entièrement la maison où je suis né. Alors je me suis embarqué sur un vaisseau tout doré, pour distraire mon chagrin. J'ai pris ma flûte sculptée, et j'ai dit une chanson à la lune; mais j'ai attristé la lune, qui s'est voilée d'un nuage.

Je me suis retourné vers la montagne, mais elle ne m'a rien inspiré.
Tot dom, gde igral ia rebenkom,

Pozhral besposhchadnyi ogon'.

Ia sel na korabl' zolochenyi, Chtob gore moe pozabyt'.

Na divno ukrashennoi fleite Igral ia vysokoi lune. 
Il me semblait que toutes les joies de mon enfance étaient brûlées dans ma maison. J'ai eu envie de mourir, et je me suis penché sur la mer. A ce moment, une femme passait dans une barque; j'ai cru voir la lune se reflétant dans l'eau. Si Elle voulait, je me rebâtirais une maison dans son coeur.

(J. Gautier 35-36)
(The cruel flames have entirely devoured the house in which I was born.

To distract my grief I then embarked in a vessel which was gilded from stem to stern. I took my carved flute, and I sang to the moon; but I saddened the moon, who veiled herself with a cloud. I turned towards the mountain, but it inspired in me no thoughts.

It seemed to me that all the joys of my childhood had burned with my house. I yearned for death, and I leaned over the sea. At that moment a woman was passing in a boat.

I took her for the moon reflecting herself in the water.

If she would only consent, I would build myself a house in her heart.

[From the French 99])
No oblakom legkim prikrylas' Luna, opechalena mnoi.

Togda ia k gore obernulsia, No pesni ne shli mne na um.

Kazalos', vse radosti detstva Sgoreli v pogibshem domu.

I mne umeret' zakhotelos', I ia naklonilsia $\mathrm{k}$ vode.

No zhenshchina v lodke skol'znula Vtorym otrazhen'em luny.

I esli ona pozhelaet,

I esli pozvolit luna,

Ia dom sebe novyi postroiu

V nevedomom serdtse ee.

(Gumilev, Stikhotvoreniia 278)

(The house where I played as a child Was devoured by merciless fire.

I embarked on a golden ship In order to forget my grief.

I played a beautifully decorated flute For the moon on high.

But the moon, saddened by me, Covered herself with a light cloud.

Then I turned to the mountain, But no songs came to mind.

It seemed that all my childhood joys Burned in the forsaken house.

And I wanted to die,

And I bent down to the water.

But a woman in a boat glided As the second reflection of the moon.

And if she wishes,

And if the moon allows

I will build a new house for myself In her mysterious heart.)

A contemporary and friend of $\mathrm{Li} \mathrm{Po}, \mathrm{Tu} F u$ (712-770) also spent most of his life on the road. Like Li Po, he held a number of important government offices, including the coveted post of imperial censor, but like Li Po he also eventually fell victim to political intrigues and ended his life in exile-hence the frequent 
notes of melancholy and the sense of loss in his poems. Another translation from Tu Fu included in The Porcelain Pavilion, "Strannik" ("Vagabond," an adaptation of "La flute d'automne" ["The Autumn Flute"]), attributes the extraordinary suffering experienced by a poet in exile to the absence in a strange land of "the sweet music of [his] mother tongue": "Ty ne slyshish' sladkoi muzyki/Materinskogo iazyka" (Gumilev, Stikhotvoreniia 277).

As we have seen, the parallels between the aestheticist agendas of Judith Gautier and Nikolai Gumilev become even more prominent when evaluated through the prism of the Chinese poetic tradition. Clearly; Chinese verse appealed to both poets in its emotional restraint, its treatment of the poetic text as primarily an artifact rather than a replica of reality, and its metapoetic content. In addition, Gumiler's lack of precision in indicating his sources reflects the concept of friendship pervasive in Chinese poems, the idea that a company of fellow poets is an important catalyst in the composition process, and that a poem thus conceived becomes collective property. Implementing the popular Chinese practice of "exchange of poems between friends" (Sunflower Splendor xvii), Gumilev freely borrowed from Gautier while creating verse that aspired to be original. In The Porelain Pavilion. the poet seems to have abandoned the principles of faithful translation he had articulated in his article "The Translator's Nine Commandments" (1919), directed to the poets working under his guidance on the first large publishing project undertaken by the nascent Bolshevik government, the "World Literature" series. ${ }^{9}$ In this article, Gumilev calls on the translator to eschew his own poetic personality and vigorously preserve the original's formal features, down to the number of stanzas and lines and the character of rhyme and meter. Gumilev practiced what he preached on many occasions-while translating the Babylonian epic Gilgamesh, for example, or Théophile Gautier's "Emaux et camées" (the only complete translation of the collection to date). However, in The Porrelain Pavilion Gumilev clearly was not aiming for accuracy, but instead secking to create pseudotranslations or variations on a theme, in the style of his Hafiz-inspired "Persian" poems written around the same time.

The last important question that remains to be considered is the extent to which these original adaptations of Chinese verse fit into ('umilev's own dialectic as a poet. Gumiler earned a reputation as an author of exuberant and dynamic poetry, in which he concealed lyricism behind the mask of a "conquistador," an explorer of exotic African and Asian lands. Invincible masculinity, jungle imagery, the cult of risk, or, as Justin Doherty calls it, "colonial adventurism" (196) in the spirit of Leconte de Lisle and Arthur Rimbaud, co-exist in Gumilev with a more restrained, philosophical, and introspective poetry. While Gumilev's refined, meditative, chamber-quality Chinese poems may scem to be at odds with his primitivist and exalted "conquistador" verse, they are consistent with his cre-

"The "Wordd Literature" series was initiated by the mastermind of proletarian literature and Socialist Realism, Maxim Gorks, who envisaged the publication of masterpieces of world literature in Russian translation with the purpose of educating the nasses. (iorky engaged many Russian writers and poets in this worth poject, providing them with much-needed financial suppon during the lean post-revolutionary yars. Cltimately, about $2(n)$ volumes nere produced in the decades wo come 
ative output as a whole if one takes into account the diversity of his poetic voices. One could even argue that the Chinese cycle of The Porcelain Parilion does not represent a departure but rather a further development of certain fundamental principles present throughout Gumilev's writing by continuing his creative exploration of exotic Oriental countries and echoing the intense visual impact and decorative quality of most of his poetry. The epic Muse that firmly guarded his poetic talent from lyrical confessions inspires the prominent narrativity of this cycle as well. Gumilev's lvric persona is again hidden behind a mask, this time that of a Chinese poet and philosopher, thereby preserving impersonality, one of the basic Acmeist requirements. Most importantly, in this cycle Gumilev returns to his dearest theme-the theme of the poet.

In the late $1910 \mathrm{~s}$, Gumilev frequently developed the theme of the poet in an Oriental context. His poems in the hand-written, illustrated booklet Persia (1921) represent the same kind of pseudo-translations or stylizations, but in this case of medieval Eastern masters as in the "Chinese" cycle. In "Podrazhanie persidskomu" ("Stylization of Persian Verse"), Gumilev imitates the traditional structure of the Arabic beit and masquerades as an unidentified Persian poet. "Persidskaia miniatiura" ("Persian Miniature") celebrates the power of the poetic word to immortalize the world of art and beauty, symbolized here by the archetypal Persian genre of miniature, which harmoniously unites the visual and the verbal. "P'ianyi dervish" ("The Drunken Dervish") is written in the form of a Sufi gazelle and exploits, according to E.P. Chudinova, the primary motifs of the fourteenthcentury Persian poet Hafiz" (9-10). In Hafiz's conception, shared by Gumilev, the poet might live as an ignoble outcast ("Ia brodiaga i trushchohnik, neputevyi chelovek," "I'm a vagabond and slum-dweller, a good-for-nothing man"), but he also possesses a prophetic gift that allows him to communicate with the Creator in a moment of mvstical revelation. Conforming to the tradition of Sufi poetry, this enlightened state is conveyed here through the motif of wine, symbol of spiritual intoxication, while God is referred to as the Friend: "Mne seichas butylka pela gromche serdtsa moego:/Mir lish' luch ot lika druga, vse inoe-ten' ego" ("The bottle sang to me just now louder than my heart: The world is just a beam from the Friend's face, the rest is his shadow, Gumilev, Stikhotvoreniia 335). Through the motifs of the poet, friendship, wine, and contempt for wealth (as well as the image of the moon over a lake) "The Drunken Dervish" echoes the main themes of The Porcelain Parilion, suggesting that a hidden metaphysical meaning may also lurk behind these concepts in the Chinese poems. After all, as Raoul Eshelman convincingly argues in his book Nikolaj Gumilev and Neoclassical Modernism, time and time again the poet's later verse projects a "metaphysical figure that Gumilev conscientiously avoids in his earlier Acmeist work" (74).

When considered in the larger context of Gumilev's verse, the Chinese adaptations appear to echo an entire array of topics and formal qualities that were

\footnotetext{
11) Gumilev's son Lev, a prominent ethnologist, identified a poem by the eleventh-century Persian poet Nasir Honrov as a subtext of this piece (cf. Gumilev, Stikhotremenia 589). This does not invalidate Chudinova's conclusions, however, as much of medieval Persian verse explored similar themes. Besides, Hafiz was an important figure for Gumilev, who made him the protagonist of his dramatic tale "Ditia Allakha" ("Allah's Child"), which focuses on the image of the model poct.
} 
characteristic of the poet's oeuvre. Moreover, Chinese verse provided vet another venue for the expression of Gumilev's apolitical stance. Published several months after the Revolution of 1917, when Russia was in the midst of a bloodv civil war, The Porcelain Pavilion, with its themes of art, love, the moon, dreaminess, and fleeting reflections in the water, was a far cry from contemporary ideological poetry born of political turmoil. Gumilev, who would himself soon fall victim to brutal political persecution, took refuge in the "porcelain pavilion" of pure poetry, vehemently advocating that art remain separate from the demands of politics and social reform.

University of Georgia

\section{Works Cited}

Camacho, Mathilde. Judith Gautier: Sa nie et son oeuzre. Paris: Librairie: E. 1)roz, 1939.

Chudinosa, E.P. "K voprosu on orientalizme Nikolaia Gumileva." Filologrcheske nauki 3 (1988): 9-15. The Complete Poms of Anua Akhmatora. Trans. Judith Hemschemeyer. Boston: Zephor Pıess, 1997.

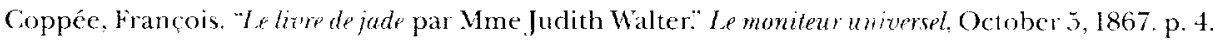
David, Henri. "Theophile Gautier: Le Pavillon surl'eau. Sources et traitement." Modern Philologr 13 (1915): 87-112 and Modern Philology 11 (1916): 151-72.

Détrie, Muriel. "I e Livm de jade de Judith Gautier: Ln live pionnier" Rane de Litleratum Compare 3 (1989): $301-24$.

- "Translation and Reception of Chinese Poetry in the West." Tamkang Rertew: A Quarterly of Comparative Studies betinen Chinese and Foreign Literalures 22. 1-4 (Fall 1991-Summer 1992): 43-57.

Doherty, Justin. The Armeist Movement in Russian Poetry: Culture and the Word. Oxford: Clarendon Press, 1995.

Eshelman, Raoul. Vikolaj Crumilen and Neoclassical Modernism: The Metuphysics of Style. Frankfurt am Main: Peter Lang. 1993.

- From the Fronch: Pastels in Prose. Trans. Stuart Merrill. New York: Harper \& Brothers, 1890.

Gautier, Judith. Le lize de jade. Paris: Alphonse Lemerre, 1867.

Gautier, Théophile. Pósies complétes. Vol. 1 \&? Paris: C. Charpentier $18 \times 4 \& 1885$.

. "Chinois et Russes a l'Exposition universelle de Paris." Le momiteur universel. Mar 1867. p. 4.

Gourmont, Rèny. Judith Gautier: Paris: Bibliothèque nationale d'édition 1904.

Gumilev, Nikolai. Stikhotoorenia i poemy. L.cningrad: Sovetskii pisatel'. 1988.

Neizdannoe inesobrannoe. Eds. M. Basker and Sh. Grei. Paris: YMCA-PRESS, 1980.

Hamao, Fusako. "The Sources of the Texts in Mahler's Lied von der Erde." Nineleenth-Cantury Music $19.1(1995): 83-95$.

D’Hervey-Saint-Denys. Poésies de leppoque des Thangs. Paris: Amyot, 1862.

Kuzmin, Mikhail. Solmanie stikhov II. Munich: Wilhelm Fink Verlag, $197 \%$

Modern Russian Poetry. Eds. Vadimir Markov and Merrill Sparks. Indianapolis: The Bobbs-Merrill Company, 1966.

Owen, Stephen. Traditional Chinese Poetry and Poetics: Omen of the World. Madison: The University of Wisconsin Press, 1985.

Le Pamasse contemporain. Vol. 1. Geneva: Slatkine Reprints, 1971.

Poems from Fronce. Ed. William Ja! Smith. New York: Thomas Y Crowell Company, 1967

Richardson, Joanna. Judith (iautier. A Biography. London: Quartet Books, 1986. 
COMPARATIVE LITERATURE $/ 164$

Sampson, Earl 11. Nikolay Gumilez. Boston: Twayne Publishers, 1979.

Schwartz, William Leonard. The Imaginative Interpretation of the Far East in Modenn French Literature 1800-1925. Paris: Librairic ancienne Honoré Champion, 1927.

Slobodniuk, S. . . "Elementy vostochnoi dukhovnosti v poezii Gumilcva." Vikolai Cumilez. Issledovaniia i materialy. Eds. M.D. Elzon and N.A. Groznova. Saint Petersburg: Nauka, 1994, 164-86.

Sunflowe Splendor. Three Thousand Years of Chinese Poetry, Eds. Wu-chi Liu and Irving Yucheng Lo. Garden City. VY: Anchor Books, 1975.

Timenchik, Roman. "Nikolai Gumilev i Vostok." Pamir 3 (1987): 123-36.

Twentieth-Century Russian Potry. Eds. John Glad and Daniel Weissbort. Lowa City: Lniversity of Iowa Press, 1992.

Two Cenluries of Russian Verse. Ed. Avrahm Yarmolinsky. Trans. Babette Deutsch. Vew York: Random House, 1966. 